\title{
Sex ratio distortion and severe inbreeding depression in the gypsy moth Lymantria dispar L. in Hokkaido, Japan
}

\author{
YASUTOMO HIGASHIURA* $\uparrow$, MICHIO ISHIHARA $\ddagger$ \& PAUL W. SCHAEFER§ \\ $\dagger$ Hokkaido Forestry Research Institute, Bibai, Hokkaido 079-0198, Japan, $\ddagger$ Biological Laboratory, Hyogo College of \\ Medicine, Nishinomiya, Hyogo 663-8501, Japan, and §USDA, Agricultural Research Service, Beneficial Insects \\ Introduction Research Laboratory, 501 South Chapel Street, Newark, DE 19713-3814, U.S.A.
}

\begin{abstract}
An abnormal female producing only female progeny was found in Lymantria dispar in Hokkaido, Japan, in July 1996. Similarly, its progeny produced only females. Egg hatch rates were near 50\% in all-female matrilines. Therefore, a certain cytoplasmic factor was thought to kill males in eggs differentially, resulting in only female hosts. In the next generation, the field population was estimated to contain $9.1 \%$ abnormal females. Severe inbreeding depression was also observed in egg hatch rates during confirmation of maternal inheritance. The cost of inbreeding was estimated at 0.395 , which is one of the highest in insects. Inbreeding avoidance by their host has been cited as one of the advantages of a male-killing factor, but we suggest that this is not applicable in this moth.
\end{abstract}

Keywords: cost of inbreeding, inbreeding depression, Lepidoptera, Lymantria dispar, male-killing, sex ratio.

\section{Introduction}

Richard Goldschmidt, in the 1920s, used local Japanese races of the gypsy moth Lymantria dispar $\mathrm{L}$. for his famous studies of sex determinants (Goldschmidt, 1934, 1940). He concluded that crosses between different sexraces resulted in abnormal sex conditions. For example, a female of a very weak race crossed to a strong male produced only sons. Inversely, the backcross, i.e. $F_{1}$ females of the cross between 'strong female' and 'very weak male' mated with 'very weak males', produced allfemale broods including both normal females and females by sex reversal (genetic males) (Goldschmidt, 1934). He characterized the Hokkaido population as a 'very weak race'. In the same location, we have accidentally found an abnormal female producing only female progeny. Goldschmidt (1934) also stated that those females produced by sex reversal rarely survived. Thus, almost all of the remaining females may be expected to produce progeny of a normal sex ratio. On the other hand, it is well known today that maternally inherited cytoplasmic factors kill male embryos to increase female progeny, i.e. hosts. The aim of this

*Correspondence. E-mail: yasu@hfri.bibai.hokkaido.jp After October 1999: Hokkaido Forestry Research Institute, Koshunai, Bibai, Hokkaido 079-0198, Japan, E-mail: yasu@1s.toyaku.ac.jp paper is to provide the results of maternal inheritance of all-female broods in crosses of progeny of the abnormal female L. dispar.

Male-killing factors, transmitted only through the female line, may bestow an advantage on females carrying the factor by reducing the number of brothers and thereby minimizing inbreeding (Werren, 1987). There are only a few experiments showing inbreeding depression in species with male-killing factors (Hurst \& Majerus, 1993). In confirmation of the maternal inheritance, we also found high inbreeding depression in a single generation of brother-sister matings. We will discuss whether inbreeding avoidance by their host is an advantage of the male-killing factor in $L$. dispar with an estimation of inbreeding and non-mating in a field population.

Although the effects of inbreeding have attracted great attention under both laboratory and field conditions (Pray \& Goodnight, 1995; Saccheri et al., 1998), these effects have been investigated very little among invertebrates, except for Drosophila and Tribolium (Roff, 1998). In species that are usually outcrossing, comparing only full-sibling lines with outbreeding lines reveals some important traits of a population, such as the cost of inbreeding and the magnitude of genetic load (Ralls et al., 1988). The effect of inbreeding varies between different life-stage periods. Saccheri et al. 
(1996) examined egg hatch rate, fecundity and some other traits affected by inbreeding in the butterfly, Bicyclus anynana. Among them, egg hatching shows the effect of inbreeding most clearly, but fecundity is also somewhat depressed. We compare egg hatch rate and fecundity among full-sibling and outbreeding lines, and the all-female brood.

Abnormal females producing only female progeny are known in many insect orders: Diptera, Hymenoptera, Coleoptera, Hemiptera and Lepidoptera (Hurst \& Pomiankowski, 1991; Hurst, 1991). To our knowledge, this is the first report of high inbreeding depression in a lepidopteran species also exhibiting all-female broods.

\section{Materials and methods}

Overwintering eggs of $L$. dispar hatch in May in Hokkaido. Larvae feed on leaves of Japanese larch Larix leptolepis, Japanese birch Betula platyphylla and many other broad-leaved trees. They pupate in July and emerge between July and September. Because females deposit all eggs en masse on tree trunks, we can recognize properties of the original female by rearing eggs from individual masses.

We collected eight egg masses in a birch forest in Bibai, Hokkaido, in February 1996. The egg masses were kept individually in plastic boxes in a cold room at $0^{\circ} \mathrm{C}$ until late May. Then, about 100 eggs from each egg mass were put in an incubator at $20^{\circ} \mathrm{C}$. After hatching, larvae and unhatched eggs were counted to give egg hatch rates. Larvae were reared to pupation on cut larch foliage. We obtained the sex ratio among pupae for each original egg mass.

In July 1996, we crossed adults from the eight egg masses in various combinations. Within a day after adult emergence, we put a female and a male into a Petri dish that was $8.5 \mathrm{~cm}$ in diameter and $8.5 \mathrm{~cm}$ high. The inner walls of the Petri dish were covered with filter paper. In October 1996, each egg mass deposited on the paper was placed in a vinyl bag and kept in the cold room. We obtained 31, 40 and 49 egg masses of crosses with abnormal females, brothersister matings and outbreeding respectively. Six nonmated females from the egg mass of the abnormal female were put into Petri dishes individually to ascertain whether producing all females was caused by parthenogenesis.

In May 1997, the eggs in each of the 120 crosses were counted to give female fecundity. There were two egg categories, infertile reddish eggs and brown embryonated eggs containing larvae. Egg embryonation begins soon after oviposition, and larvae are fully formed inside the egg in about a month. We reared 101-240 eggs of each cross to obtain egg hatch rates, except for two inbreeding and one outbreeding egg masses, which contained only infertile eggs. We reared larvae of 19,5 and 13 egg masses of crosses with abnormal females, brother-sister matings and outbreeding respectively. All reared larvae were fed foliage of cut larch. The sex ratio of the progeny of each cross was obtained in the adults in July 1997.

During August and September 1996, vinyl flagging tape was fastened to every tree trunk bearing egg masses in the birch forest ( 0.2 ha in area) from which we collected the egg mass of the abnormal female in the previous generation. Marks were put on the tape to indicate egg mass positions, and above-ground heights were recorded. In October 1996, we collected about 80 eggs in each egg mass deposited below $4.8 \mathrm{~m}$. Because the number of eggs contained in each egg mass is highly correlated with the product of length times width of the egg mass (Higashiura \& Kamijo, 1978), the length and width of each egg mass were recorded at the time of egg collection. All eggs were kept as an individual egg mass in the cold room. About 30 eggs in each egg mass were placed in the incubator $\left(20^{\circ} \mathrm{C}\right)$ in February 1997. After hatching, eggs and hatched larvae were counted to give egg hatch rates. In May 1997, using the same method as above, we reared all seven egg batches whose hatch rates had been less than $70 \%$, and another seven egg batches whose hatch rates had been more than $70 \%$, until adults emerged in July 1997. In this way, fecundity, fertility, egg hatch rate and sex ratio were estimated for the field population.

Fisher's randomization method with 5000 replications was used to test the null hypothesis that the sex ratio was 1:1 (Manly, 1997).

\section{Results}

All 41 reared larvae from one of the eight egg masses became female pupae (Fig. 1). The sex ratio was significantly different from 1:1 $(P=0)$. The sex ratios in the other matriline were not different from 1:1 $(P>0.2)$. The percentage of eggs hatching in this one egg mass was only $57 \%$, whereas in all others, it exceeded $97 \%$.

Progenies from the abnormal female, designated fe- 6 , were all females (Table 1a). The sex ratios of the progenies were statistically different from 1:1 $(P<$ $0.001)$. Sib-matings did not skew the sex ratio $(P=0.091$ in no. 55 and $P>0.5$ in all others; Table $1 \mathrm{~b})$. The sex ratios of outbreeding pairs, except for fe-6, were not different from 1:1 $(P>0.1)$, although $65 \%$ of the progeny of no. 88 became females $(P=0.013)$. Six fe-6 non-mated females deposited only infertile eggs.

All pairs of mean egg hatch rates were significantly different from each other among the three types of 


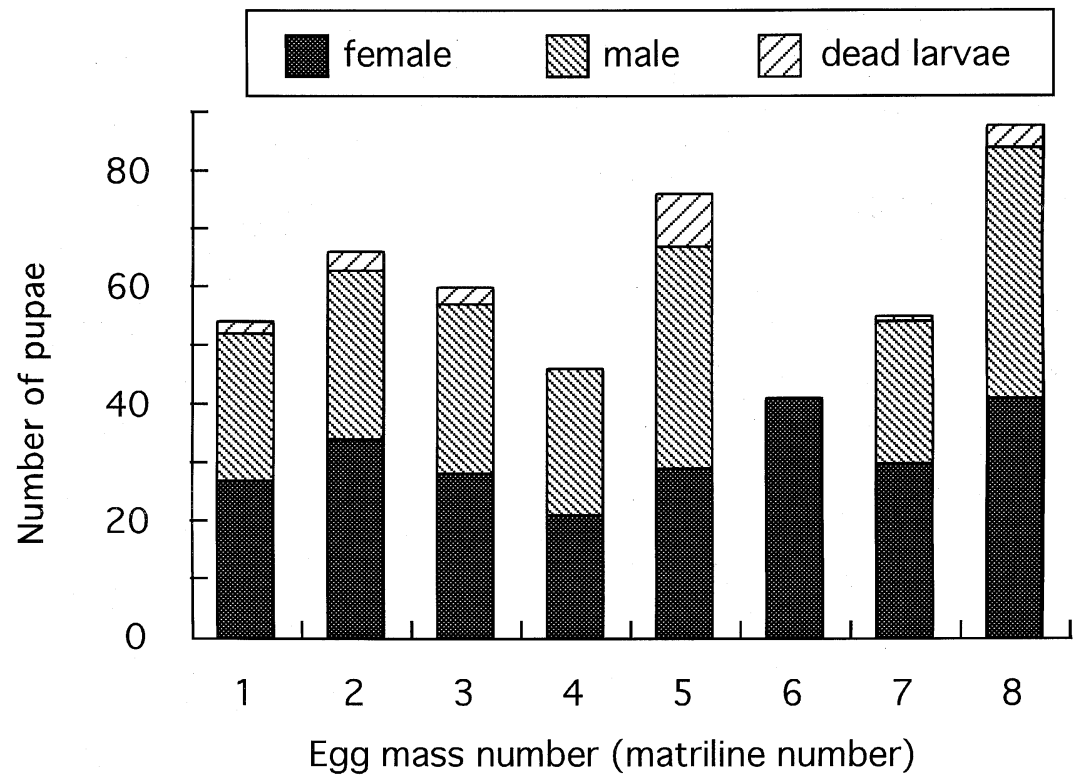

Fig. 1 Number of pupae in each sex in the eight egg masses of Lymantria dispar collected in Hokkaido, Japan, inFebruary 1996. progenies (ANOVA for unbalanced data using the arcsine transformation: $F_{2,114}=146.14, \quad P<0.0001 ; \quad$ SAS Institute, 1990) (Tukey's studentized range test using the arcsine transformation: $\mathrm{MSE}=0.0602, P<0.05$; SAS Institute, 1990) (Fig. 2). The mean egg hatch rate of all-female matrilines $(0.475 \pm 0.018$ : mean $\pm 95 \%$ CL) was lower than that of inbreeding pairs $(0.580 \pm 0.075)$ and that of outbreeding pairs, except for fe-6 $(0.959 \pm 0.018)$. Egg hatch rates of all-female matrilines were distributed in a narrow range around 0.5 (Fig. 2a). Egg hatch rate of 38 pairs in one generation of brother-sister matings were scattered between 0.117 and 1.00 (Fig. 2c). Only seven sib-matings in five matrilines had more than $80 \%$ egg hatching. There were no particular inbreeding lines escaping the depression, because the mean hatch rates were not different among inbreeding lines (ANOVA for unbalanced data using the arcsine transformation: $F_{6,31}=0.61, P>0.7$ ). Almost all of the outbreeding pairs had more than $90 \%$ egg hatch rates (Fig. 2b).

Unfertilized reddish eggs were usually less than $10 \%$ of total eggs and packed at the end of each individual egg mass, i.e. deposited last. On the other hand, unhatched brown eggs were distributed randomly throughout egg masses of all-female broods. Dead larvae were fully formed inside unhatched eggs of these broods. Hatching larvae were never observed eating unhatched eggs.

Fecundity was also different among the three types of pairs (ANOVA for unbalanced data: $F_{2,117}=6.55$, $P<0.002$ ) (Fig. 3). The mean fecundity of the progenies of the abnormal female (601 \pm 42 eggs) was the smallest and significantly different from the other two pairs (Tukey's studentized range test:
$\mathrm{MSE}=21492.97, P<0.05)$. The difference in mean fecundity, however, was not significant between inbreeding (699 \pm 55 eggs) and outbreeding pairs (719 \pm 41 eggs) $(P>0.05)$.

After hatching, the viability to adults was $90 \pm 3 \%$, $82 \pm 15 \%$ and $91 \pm 4 \%$ in all-female matrilines, inbreeding and outbreeding pairs respectively. The difference was not significant (ANOVA for unbalanced data using the arcsine transformation: $F_{2,34}=1.99$, $P>0.15)$ (Table 1).

We collected eggs from 68 out of 82 egg masses in the 0.2 ha birch forest. A trimodal distribution was observed in egg hatch rates in the field population (Fig. 4). The first mode was at zero hatch rate for the two egg batches containing only infertile eggs. After hatching in June 1997, we collected all eggs of those two egg masses and ascertained that they contained only infertile eggs. The second mode consisted of eggs of all-female broods according to our rearing results (Table 2). The last mode was probably for normal sex ratio broods, in which two of the eight broods (nos f13 and f46) had heterogeneous sex ratios and produced an excess of males or females respectively $(P=0.0184$ and $P=0.00740$ ) (Table 2). Egg masses higher than $4.8 \mathrm{~m}$ were not collected or analysed. But the height distributions were not different among egg masses of unfertilized, all-female broods and normal sex ratio broods below $4.8 \mathrm{~m}$ (ANOVA for unbalanced data: $\left.F_{2,65}=0.60, P>0.5\right)$. Therefore, we estimated the frequencies of unfertilized and all-female broods from that egg mass collection, or $2 / 68=2.9 \%$ non-mating females, and $6 / 66=9.1 \%$ abnormal females in this field population. The egg mass sizes were not different 
Table 1 Results of crosses made involving abnormal females and normal adults from eight egg masses of gypsy moth Lymantria dispar collected at Bibai, Hokkaido, Japan, in February 1996

\begin{tabular}{|c|c|c|c|c|c|}
\hline $\begin{array}{l}\text { Individual } \\
\text { no. }\end{array}$ & Parents $\dagger$ & $\begin{array}{c}\text { Number } \\
\text { of larvae } \\
\text { reared }\end{array}$ & $\begin{array}{c}\text { Number } \\
\text { of } \\
\text { females }\end{array}$ & $\begin{array}{c}\text { Number } \\
\text { of } \\
\text { males }\end{array}$ & $P$ \\
\hline \multicolumn{6}{|c|}{ (a) Crosses of abnormal females } \\
\hline 6 & fe- $6 \times$ ma- 1 & 91 & 81 & 0 & $* * *$ \\
\hline 12 & $\mathrm{fe}-6 \times \mathrm{ma}-1$ & 49 & 47 & 0 & $* * *$ \\
\hline 15 & fe- $6 \times$ ma- 1 & 56 & 54 & 0 & $* * *$ \\
\hline 16 & fe- $6 \times$ ma- 1 & 50 & 44 & 0 & $* * *$ \\
\hline 5 & fe- $6 \times$ ma- 2 & 55 & 40 & 0 & $* * *$ \\
\hline 19 & fe- $6 \times$ ma- 2 & 44 & 40 & 0 & $* * *$ \\
\hline 8 & fe- $6 \times \mathrm{ma}-3$ & 40 & 33 & 0 & $* * *$ \\
\hline 11 & fe- $6 \times \mathrm{ma}-3$ & 53 & 45 & 0 & $* * *$ \\
\hline 20 & $\mathrm{fe}-6 \times \mathrm{ma}-4$ & 62 & 52 & 0 & $* * *$ \\
\hline 21 & $\mathrm{fe}-6 \times \mathrm{ma}-4$ & 54 & 52 & 0 & $* * *$ \\
\hline 1 & $\mathrm{fe}-6 \times \mathrm{ma}-5$ & 65 & 62 & 0 & $* * *$ \\
\hline 9 & fe- $6 \times$ ma- 5 & 24 & 22 & 0 & $* * *$ \\
\hline 10 & fe- $6 \times$ ma- 5 & 66 & 65 & 0 & $* * *$ \\
\hline 4 & fe- $6 \times$ ma- 7 & 25 & 22 & 0 & $* * *$ \\
\hline 7 & $\mathrm{fe}-6 \times \mathrm{ma}-7$ & 50 & 41 & 0 & $* * *$ \\
\hline 17 & $\mathrm{fe}-6 \times \mathrm{ma}-7$ & 51 & 46 & 0 & $* * *$ \\
\hline 2 & $\mathrm{fe}-6 \times \mathrm{ma}-8$ & 68 & 66 & 0 & $* * *$ \\
\hline 13 & fe- $6 \times$ ma- 8 & 13 & 12 & 0 & $* * *$ \\
\hline 18 & fe- $6 \times$ ma- 8 & 44 & 44 & 0 & $* * *$ \\
\hline
\end{tabular}

(b) Crosses of normal adults including brother-sister matings

\begin{tabular}{|c|c|c|c|c|c|}
\hline 26 & $\mathrm{fe}-1 \times \mathrm{ma}-1$ & 24 & 11 & 9 & \\
\hline 76 & $\mathrm{fe}-1 \times \mathrm{ma}-3$ & 104 & 48 & 40 & \\
\hline 90 & $\mathrm{fe}-1 \times \mathrm{ma}-4$ & 56 & 26 & 28 & \\
\hline 68 & fe-1 1 ma-5 & 41 & 17 & 20 & \\
\hline 54 & $\mathrm{fe}-2 \times \mathrm{ma}-2$ & 34 & 10 & 11 & \\
\hline 86 & $\mathrm{fe}-2 \times \mathrm{ma}-3$ & 47 & 23 & 17 & \\
\hline 64 & $\mathrm{fe}-3 \times \mathrm{ma}-2$ & 63 & 37 & 26 & \\
\hline 48 & $\mathrm{fe}-3 \times \mathrm{ma}-3$ & 6 & 3 & 2 & \\
\hline 72 & $\mathrm{fe}-3 \times \mathrm{ma}-4$ & 27 & 14 & 12 & \\
\hline 81 & $\mathrm{fe}-3 \times \mathrm{ma}-7$ & 42 & 15 & 24 & \\
\hline 63 & $\mathrm{fe}-4 \times \mathrm{ma}-1$ & 73 & 30 & 24 & \\
\hline 88 & $\mathrm{fe}-4 \times \mathrm{ma}-3$ & 64 & 36 & 19 & $*$ \\
\hline 52 & fe- $5 \times$ ma- 5 & 61 & 26 & 29 & \\
\hline 71 & $\mathrm{fe}-5 \times \mathrm{ma}-8$ & 4 & 3 & 1 & \\
\hline 78 & $\mathrm{fe}-7 \times \mathrm{ma}-3$ & 61 & 28 & 28 & \\
\hline 59 & fe- $7 \times$ ma-5 & 61 & 32 & 22 & \\
\hline 55 & $\mathrm{fe}-7 \times \mathrm{ma}-7$ & 14 & 9 & 4 & \\
\hline 58 & fe- $8 \times$ ma- 5 & 54 & 26 & 26 & \\
\hline
\end{tabular}

The sex ratio was significantly different from 1:1 at: ${ }^{*} P<0.05$, $* * P<0.01, * * * P<0.001$.

†'Parents' shows sex (female and male) and identification number of the eight egg masses. Adults from no. 6 egg mass were all females, or fe-6. Crosses with the same numbers for both females and males indicate brother-sister matings (five in all).

among the three types of broods in the field (ANOvA for unbalanced data: $F_{2,65}=0.12, P>0.8$ ).
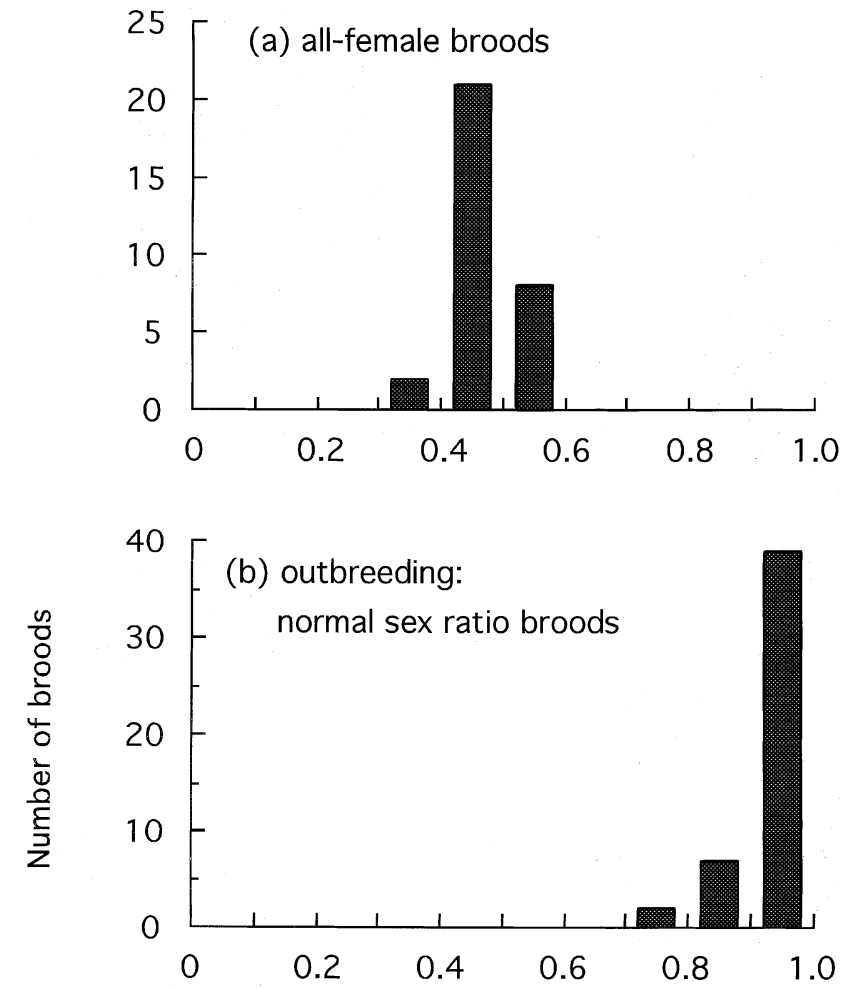

(c) full-sib mating: normal sex ratio broods

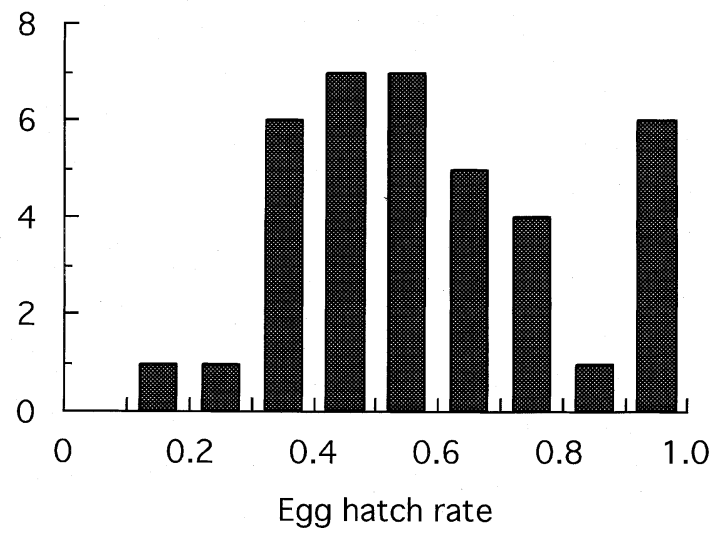

Fig. 2 Frequency distributions of egg hatch rates in (a) allfemale broods; (b) outbreeding of normal sex-ratio broods; and (c) inbreeding of normal sex-ratio broods of Lymantria dispar. Egg hatch rates were obtained by rearing from 101 to 240 eggs in each cross.

\section{Discussion}

Abnormal females producing only female progeny

The Hokkaido population of Lymantria dispar is referred to as a 'very weak' sex-race (Goldschmidt, 1934, 1940). Therefore, it is possible to produce allfemale broods by the transport of 'strong females', which live in Aomori Prefecture adjacent to Hokkaido, 


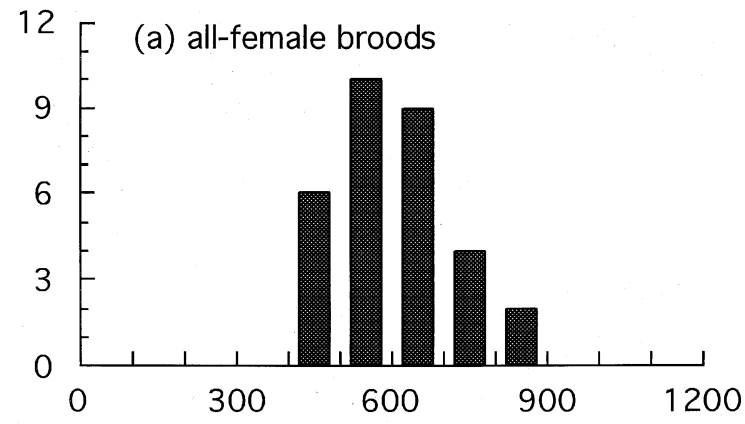

(b) outbreeding: normal sex ratio broods

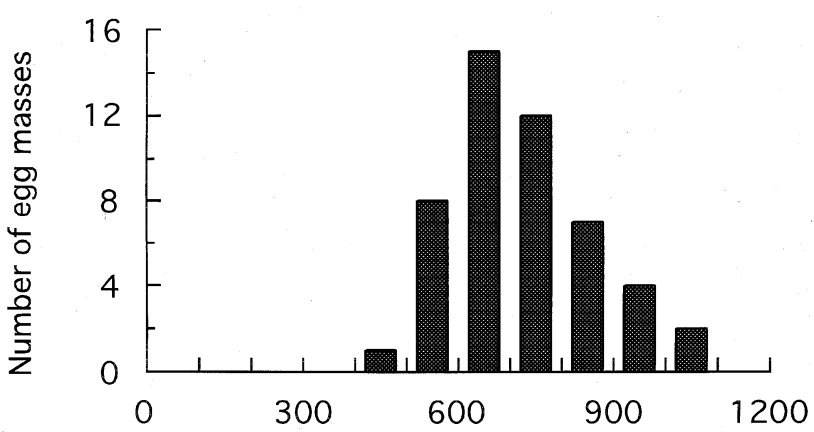

(c) full-sib mating: normal sex ratio broods

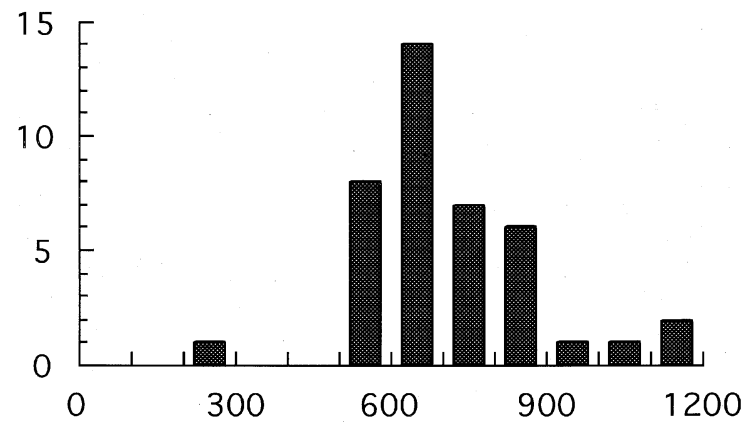

Number of eggs per mass (laid by a female)

Fig. 3 Frequency distribution of fecundities in (a) all-female broods; (b) outbreeding of normal sex-ratio broods; and

(c) inbreeding of normal sex-ratio broods of Lymantria dispar.

according to the theory of Goldschmidt (1934). But he never observed females by sex reversal, because such females rarely survived. If we had collected such an all-female brood in one of the eight egg masses, surviving females would have been normal genetic females, and both males and females would have appeared at a normal sex ratio. The entire progeny reared from the abnormal female, however, produced only female adults, irrespective of the mating male. Six fe-6 non-mated females deposited only infertile eggs, suggesting that the phenomenon is not parthenogenesis. Egg hatch rates of abnormal females were distributed in a narrow range around 0.5 . In our study, a maternally inherited cytoplasmic factor differentially killed male

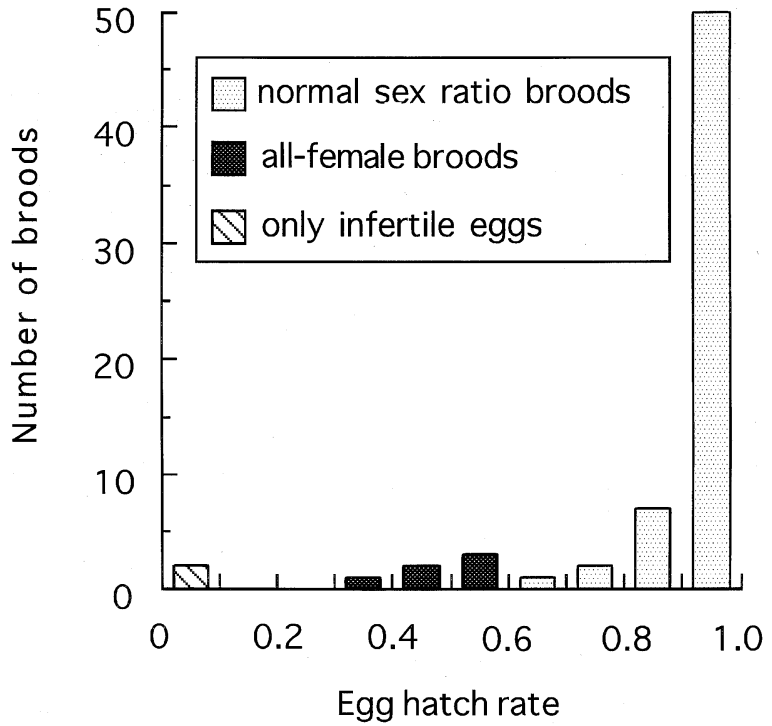

Fig. 4 Frequency distribution of egg hatch rates in the field population of Lymantria dispar in Hokkaido, Japan. The eggs were deposited in August and September 1996. Egg hatch rates were obtained by rearing from 22 to 165 eggs in each egg mass. Two egg masses contained only infertile eggs and are plotted at zero hatch rate. Only those egg masses having egg hatch rates between 0.32 and 0.55 produced only female adults shown in Table 2.

Table 2 Sex ratios of Lymantria dispar egg masses collected in a birch forest, Bibai, Hokkaido, Japan, in October 1996. This is the same 0.2 ha birch forest in which the abnormal female was collected in the previous generation in February 1996

\begin{tabular}{|c|c|c|c|c|c|}
\hline $\begin{array}{l}\text { Individual } \\
\text { no. }\end{array}$ & $\begin{array}{c}\% \text { egg } \\
\text { hatch rate }\end{array}$ & $\begin{array}{c}\text { Number } \\
\text { of larvae } \\
\text { reared }\end{array}$ & $\begin{array}{c}\text { Number } \\
\text { of } \\
\text { females }\end{array}$ & $\begin{array}{c}\text { Number } \\
\text { of } \\
\text { males }\end{array}$ & $P$ \\
\hline \multicolumn{6}{|c|}{ (A) Egg masses with hatch rate between $30 \%$ and $60 \%$} \\
\hline f15 & 50.3 & 43 & 41 & 0 & $* * *$ \\
\hline f16 & 45.0 & 18 & 17 & 0 & $* * *$ \\
\hline $\mathrm{f} 41$ & 54.3 & 24 & 24 & 0 & $* * *$ \\
\hline f59 & 47.1 & 15 & 15 & 0 & $* * *$ \\
\hline f69 & 54.5 & 37 & 36 & 0 & $* * *$ \\
\hline f81 & 32.3 & 9 & 9 & 0 & $* *$ \\
\hline \multicolumn{6}{|c|}{ (B) Egg masses with hatch rate more than $60 \%$} \\
\hline $\mathrm{f} 3$ & 95.1 & 15 & 9 & 6 & \\
\hline f13 & 93.4 & 50 & 15 & 32 & * \\
\hline $\mathrm{f} 24$ & 85.7 & 4 & 2 & 2 & \\
\hline f26 & 96.7 & 52 & 25 & 25 & \\
\hline $\mathrm{f} 46$ & 98.0 & 52 & 35 & 17 & $* *$ \\
\hline f56 & 96.7 & 57 & 22 & 34 & \\
\hline f71 & 98.9 & 51 & 25 & 21 & \\
\hline f80 & 69.1 & 16 & 7 & 8 & \\
\hline
\end{tabular}

The sex ratio was significantly different from 1:1 at: $* P<0.05$, $* * P<0.01, * * * P<0.001$.

(c) The Genetical Society of Great Britain, Heredity, 83, 290-297. 
Table 3 Differences in viability between outbreeding $(F=0)$ and inbreeding $(F=0.25)$ pairs, cost of inbreeding $(i)$ at $F=0.25$, and $B$ for a measure of the rate at which survival decreases with increasing inbreeding (Morton et al., 1956) in 10 insect species

\begin{tabular}{|c|c|c|c|c|c|}
\hline \multirow[b]{2}{*}{ Species } & \multirow[b]{2}{*}{ Component } & \multicolumn{2}{|c|}{ Survival rates $(\%)$} & \multirow{2}{*}{$\begin{array}{c}\text { Cost of } \\
\text { inbreeding } \\
i\end{array}$} & \multirow[b]{2}{*}{$B$} \\
\hline & & $\begin{array}{l}\text { Outbreeding } \\
\qquad(F=0)\end{array}$ & $\begin{array}{l}\text { Full-sib } \\
(F=0.25)\end{array}$ & & \\
\hline $\begin{array}{l}\text { Orthoptera } \\
\text { (1) Gryllus firmus }\end{array}$ & Egg hatching & & & 0.0473 & 0.194 \\
\hline $\begin{array}{l}\text { Coleoptera } \\
\text { (2) Tribolium castaneum }\end{array}$ & Egg-early larva viability & 41.4 & 36.6 & 0.116 & 0.493 \\
\hline $\begin{array}{l}\text { Diptera } \\
\text { (3) Drosophila melanogaster } \\
\text { (4) Drosophila pseudoobscura } \\
\text { (5) Musca domestica }\end{array}$ & $\begin{array}{l}\text { Egg-pupa viability } \\
\text { Egg-adult viability } \\
\text { Egg-adult viability }\end{array}$ & $\begin{array}{l}80 \\
88.7 \\
75\end{array}$ & $\begin{array}{l}69 \\
71.4 \\
51\end{array}$ & $\begin{array}{l}0.14 \\
0.195 \\
0.32\end{array}$ & $\begin{array}{l}0.60 \\
0.868 \\
1.5\end{array}$ \\
\hline $\begin{array}{l}\text { Lepidoptera } \\
\text { (6) Lymantria dispar } \\
\text { (7) Bicyclus anynana } \\
\text { (8) Heliconius erato } \\
\text { (9) Dryas iulia } \\
\text { (10) Melitaea cinxia } \\
\text { (10) Melitaea cinxia }\end{array}$ & $\begin{array}{l}\text { Egg hatching } \\
\text { Egg hatching } \\
\text { Egg hatching } \\
\text { Egg hatching } \\
\text { Egg hatching } \\
\text { Egg hatching }\end{array}$ & $\begin{array}{l}95.9 \\
81 \\
92 \\
91 \\
69 \\
79\end{array}$ & $\begin{array}{l}58.0 \\
21 \\
67 \\
60 \\
37 \\
60\end{array}$ & $\begin{array}{l}0.395 \\
0.74 \\
0.27 \\
0.34 \\
0.46 \\
0.24\end{array}$ & $\begin{array}{l}2.01 \\
5.4 \\
1.3 \\
1.7 \\
2.5 \\
1.1\end{array}$ \\
\hline
\end{tabular}

(1) Roff (1998); (2) Fernández et al. (1995); (3) García et al. (1994); (4) Dobzhansky et al. (1963); (5) Bryant et al. (1986); (6) This study; (7) Saccheri et al. (1996); (8) Di Mare \& Araújo (1986); (9) Haag \& Araújo (1994); (10) Saccheri et al. (1998).

embryos. Abnormal females producing only female progeny are found in many insect orders. To the 12 recorded species of Lepidoptera (Ishihara, 1994), L. dispar should now be added. Although a causative agent has not actually been identified in any of these lepidopteran species, Jiggins et al. (1998) first found evidence of a male-killing bacterium as a causative agent of female-biased sex ratios in Acraea encedon, indicating 'cure' of the trait by antibiotic treatment. Further studies are needed to identify the causative agent of all-female broods in L. dispar. All-female broods of L. dispar have not been detected in North America (Myers et al., 1998).

In the next generation, the percentage of all-female broods was $9.1 \%$ in the same birch forest, because six out of 66 egg masses produced only female progeny. The egg hatch rates were more than $65 \%$ in normal sex ratio broods in our field collection. Therefore, the frequency of all-female broods can be estimated by counting the frequency of egg batches whose egg hatch rates are between $30 \%$ and $60 \%$. The mean fecundity of allfemale matrilines was significantly lower under laboratory conditions, but not lower in the field, than that of outbreeding normal sex ratio broods. To persist in a population, all-female broods need to produce more females than normal sex ratio broods. This condition leads the population to contain too many females and into extinction without dispersing all female broods widely or recovering to normal sex ratio (Ishihara, 1992, 1994). Recovery was not observed in L. dispar. We need further studies to reveal the mechanisms of persistence of this condition in the field population.

\section{Inbreeding depression}

Severe inbreeding depression was found in egg hatch rates under laboratory conditions in L. dispar. The extent of the depression varied widely irrespective of line. Also, some broods escaped this depression. But fecundity and viability after hatching were not different between inbreeding and outbreeding pairs. Saccheri et al. (1996) have also pointed out and discussed that the inbreeding depression in fecundity is weaker than that in hatch rate.

There were no inbreeding broods in the field population. Therefore, the inbreeding coefficient $(F)$ was thought to be zero in the broods of pairs from different original egg masses. According to Ralls et al. (1988), we can estimate the cost of inbreeding ( $i$ ) in a single generation of brother-sister matings (the inbreeding coefficient, $F=0.25$ ) from egg hatch rate as follows:

$i=1 \quad(\mathrm{IN} / \mathrm{OUT})$,

where IN and OUT stand for the mean egg hatch rate of inbreeding $(F=0.25)$ and outbreeding $(F=0)$ pairs 
respectively. The mean hatch rates were 0.580 (38 egg masses) and 0.959 (48 egg masses) for inbreeding and outbreeding pairs respectively. Therefore, the cost of inbreeding from egg hatch rate is estimated at 0.395 (95\% confidence interval of $0.304-0.483$ ). The cost of inbreeding at $F=0.25$ may also be represented as follows (Ralls et al., 1988):

$i=1 \quad \exp (0.25 B)$,

where $B$ is a measure of the rate at which survival decreases with increased inbreeding. Then $B$ may be estimated using $i$, if the Morton et al. (1956) model is applied.

$B=4 \ln (1 \quad i)$,

and $B$ for that population of $L$. dispar is 2.01 . Thus, $B$ and $i$ are among the largest in insects investigated hitherto (Table 3). The number of lethal equivalents per zygote or individual is usually twice the value of $B$ (Morton et al., 1956; Ralls et al., 1988; but see Dobzhansky et al., 1963). Thus, each individual L. dispar in that population is estimated to have the equivalent of four lethal recessive genes in heterozygous conditions.

Recently, inbreeding depression has been found substantially to affect the fitness components, such as egghatching rate, in natural populations (Keller, 1998; Saccheri et al., 1998). But the effect of inbreeding has been investigated only in subdivided populations and in limited genera. The estimation of the cost of inbreeding is not painstaking and reveals the variation in the magnitude of genetic load in natural populations (Keller, 1998; Saccheri et al., 1998). In comparison with other insect orders, Table 3 shows that inbreeding depression is generally severe in Lepidoptera. In Acraea encedon, however, the egg-hatching rates of sib-matings were not lower than those of normal matrilines (Jiggins et al., 1998). After the removal of lethal genes, fitness recovered rapidly in bottlenecked populations (Saccheri et al., 1996). The population of L. dispar in North America was founded by limited numbers of individuals (Liebhold et al., 1989). However, Rossiter (1987) found some genetic variation in the population. The genetic load of such bottlenecked populations is most interesting.

\section{Advantage of killing males}

Although the evidence is scarce, inbreeding avoidance by their host has been cited as one of the advantages of a male-killing factor (Werren, 1987). Hurst et al. (1997) stated that the prerequisite condition for this advantage to occur was some level of inbreeding and suffering some level of inbreeding depression. However, there are only a few experiments showing inbreeding depression in species with a male-killing factor (Hurst \& Majerus, 1993; Hurst et al., 1997). A second advantage may be that, by killing males, increased resources become available to sibling females. This advantage is easily applicable to insects living on limited resources, such as hymenopteran endoparasitoids or bark beetles (Scolytidae) (Hurst \& Majerus, 1993). Furthermore, dead male eggs provide added resources through egg cannibalism to their sisters bearing clonal cytoplasmic factors; this is known in Coccinellidae and the butterfly Acraea encedon (Hurst et al., 1997; Jiggins et al., 1998). These two advantages are in early male-killing types, in which cytoplasmic factors kill males either during embryogenesis or during the first instar (Hurst, 1991). The third advantage is that the microbe from dead males is transferred horizontally and in late male-killing, in which the factor kills males during the fourth instar or later (Hurst, 1991). In L. dispar, male death is probably in developed larvae in egg shells. Therefore, the former two advantages are relevant. However, we conclude that, for $L$. dispar, these hypotheses are not applicable because hatching larvae of $L$. dispar disperse widely and then feed among larvae from many other broods. A small percentage of females were unable to mate with males and deposited only infertile eggs in the field. Therefore, the males were not in excess in the population. Hurst et al. (1996) estimated the rate of inbreeding in the field and pointed out that inbreeding avoidance is not advantageous in Adalia bipunctata because of the rare occurrence of inbreeding. Evidence of inbreeding was also not found in the field in L. dispar. Moreover, resource advantage may not be adopted in male-killing in $L$. dispar, as we have never seen larvae feeding on unhatched eggs. A new hypothesis may be needed to explain the evolutionary advantage of male-killing in L. dispar.

\section{Acknowledgements}

We thank Sandy Liebhold, without whose request to rear $L$. dispar larvae for a pupal predation study, this research would not have begun. We are very grateful to Michiko, Kyousuke and Takuro Higashiura for their help in rearing larvae. We are also grateful to Kihachiro Kikuzawa for his review of an early draft. We thank anonymous referees for their helpful comments to improve this manuscript.

\section{References}

BRYANT, E. H., MCCOMmAS, S. A. AND COMBS, L. M. 1986. The effect of an experimental bottleneck upon quantitative genetic variation in the housefly. Genetics, 114, 1191-1211. 
DI MARE, R. A. AND ARAÚJO, A. M. 1986. A first survey of inbreeding effects in Heliconius erato phyllis (Lepidoptera; Nymphalidae). Rev. Brasil. Genet., 9, 11-20.

DOBZHANSKY, T., SPASSKY, B. AND TIDWELL, T. 1963. Genetics of natural populations. XXXII. Inbreeding and the mutational and balanced genetic loads in natural populations of Drosophila pseudoobscura. Genetics, 48, 361-373.

FERNÁNDEZ, A., TORO, M. A. AND LóPEZ-FANJUL, C. 1995. The effect of inbreeding on the redistribution of genetic variance of fecundity and viability in Tribolium castaneum. Heredity, 75, 376-381.

GARCÍA, N., LÓPEZ-FANJUL, C. AND GARCÍA-DORADO, A. 1994. The genetics of viability in Drosophila melanogaster: effects of inbreeding and artificial selection. Evolution, 48, 1277-1285.

GOLDSCHMIDT, R. 1934. Lymantria. Bibl. Genet., 11, 1-185.

GOLDSChMidT, R. 1940. The Material Basis of Evolution. Yale University Press, New Haven, CT (reprinted by Pageant, New Jersey, 1960).

HAAG, K. L. AND ARAÚJO, A. M. 1994. Inbreeding, genetic load and morphometric variation in natural populations of Dryas iulia (Lepidoptera, Nymphalidae). Rev. Brasil. Genet., 17, 35-39.

HIGASHIURA, Y. AND KAMIJO, K. 1978. Mortality factors during the declining phase of a gypsy moth outbreak in a larch plantation in Hokkaido, Japan. Bull. Hokkaido For. Exp. Stn., 15, 9-16.

HURST, G. D. D., HURST, L. D. AND MAJERUS, M. E. N. 1997. Cytoplasmic sex-ratio distorters. In: O’Neill, S. L. Hoffman, A. A. and Werren, J. H. (eds) Influential Passengers: Inherited Microorganisms and Arthropod Reproduction, pp. 125-154. Oxford University Press, Oxford.

HURST, G. D. D. AND MAJERUS, M. E. N. 1993. Why do maternally inherited microorganisms kill males? Heredity, 71, 81-95.

HURST, G. D. D., SLOGGETT, J. J. AND MAJERUS, M. E. N. 1996. Estimation of the rate of inbreeding in a natural population of Adalia bipunctata (Coleoptera: Coccinellidae) using a phenotypic indicator. Eur. J. Entomol., 93, 145-150.

HURST, L. D. 1991. The incidences and evolution of cytoplasmic male killers. Proc. R. Soc. B, 244, 91-99.

HURST, L. D. AND POMIANKOWSKI, A. 1991. Causes of sex ratio bias may account for unisexual sterility in hybrids: a new explanation of Haldane's rule and related phenomena. Genetics, 128, 841-858.

ISHIHARA, M. 1992. Persistence of females that produce only female progeny in Lepidoptera. Res. Popul. Ecol., 34, 331-347.
ISHIHARA, M. 1994. Persistence of abnormal females that produce only female progeny with occasional recovery to normal females in Lepidoptera. Res. Popul. Ecol., 36, 261-269.

JIGGINS, F. M., HURST, G. D. D. AND MAJERUS, M. E. N. 1998. Sex ratio distortion in Acraea encedon (Lepidoptera: Nymphalidae) is caused by a male-killing bacterium. Heredity, 81, 87-91.

KELLER, L. F. 1998. Inbreeding and its fitness effects in an insular population of song sparrows (Melospiza melodia). Evolution, 52, 240-250.

LIEBHOLD, A., MASTRO, v. AND SCHAEFER, P. W. 1989. Learning from the legacy of Léopold Trouvelot. Bull. Entomol. Soc. Am., 35, 20-22.

MANLY, B. F. J. 1997. Randomization, Bootstrap and Monte Carlo Methods in Biology, 2nd edn. Chapman \& Hall, London.

MORTON, N. E., CROW, J. F. AND MULLER, H. J. 1956. An estimate of the mutational damage in man from data on consanguineous marriages. Proc. Natl Acad. Sci. U.S.A., 42, 855863.

MYERS, J. H., BOETTNER, G. AND ELKINTON, J. 1998. Maternal effects in gypsy moth: only sex ratio varies with population density. Ecology, 79, 305-314.

PRAY, L. A. AND GOODNIGHT, C. J. 1995. Genetic variation in inbreeding depression in the red flour beetle Tribolium castaneum. Evolution, 49, 176-188.

RALlS, K., BALlOU, J. D. AND TEMPLETON, A. 1988. Estimates of lethal equivalents and the cost of inbreeding in mammals. Conserv. Biol., 2, 185-193.

ROFF, D. A. 1998. Effects of inbreeding on morphological and life history traits of the sand cricket, Gryllus firmus. Heredity, 81, 28-37.

ROSSITER, M. C. 1987. Genetic and phenotypic variation in diet breadth in a generalist herbivore. Evol. Ecol., 1, 272-282.

SACCHERI, I. J., BRAKEFIELD, P. M. AND NICHOLS, R. A. 1996. Severe inbreeding depression and rapid fitness rebound in the butterfly Bicyclus anynana (Satyridae). Evolution, 50, 2000-2013.

SACCHERI, I., KUUSSAARI, M., KANKARE, M., VIKMAN, P., FORTELIUS, W. AND HANSKI, I. 1998. Inbreeding and extinction in a butterfly metapopulation. Nature, 392, 491-494.

SAS INSTITUTE. 1990. SAS/STAT User's Guide, Version 6, 4th edn. SAS Institute Inc., Cary, NC.

WERREN, J. H. 1987. The coevolution of autosomal and cytoplasmic sex ratio factors. J. Theor. Biol., 124, 317-334. 